\title{
Compatibility of fungal bioagent for bacterial leaf blight of rice with chemical pesticides, commonly used in rice cultivation
}

\author{
Gokil Prasad Gangwar \\ Department of Plant Pathology, G. B. Pant University of Agriculture and Technology, Pantnagar, 263 145, INDIA \\ E-mail: gokil_prasad@rediffmail.com \\ Received: J uly 23, 2013; Revised received: August 26, 2013; Accepted: August 28, 2013
}

Abstract:Though the pesticides have adverse effects but they still are very important in crop protection. Hence, present study on compatibility of fungal bioagent (Trichoderma harzianum) of bacterial leaf blight of rice with chemical pesticides which are commonly used in rice cultivation was carried out with aim to look the possibilities of integrating biological control with chemical control to manage bacterial leaf blight of rice effectively. All the chemical pesticides (fungicides, antibiotic, insecticides and herbicides) exhibited varying adverse effect on mycelial growth of T. harzianum but none of these was antisporulant. Among fungicides and antibiotic, copper oxychloride and streptocycline was compatible with T. harzianum at all concentrations $(2000,1000,500$ and $250 \mathrm{ppm})$ but mancozeb exhibited compatibility only on lower concentrations (500 and $250 \mathrm{ppm}$ ). All insecticides and herbicides were compatible with T. harzianum at all concentrations $(2000,1000,500$ and 250 ppm). Further studies are required in this area of research.

Keywords: Bacterial leaf blight of rice, Compatibility, Fungicides, Herbicides, Insecticides, Trichoderma harzianum

\section{INTRODUCTION}

The prime importance in the agriculture is to increase the productivity with ensured food safety. Though the pesticides have adverse effects but they still are very importance in crop protection. Bioagents being a biological entity are influenced by various factors which may also affect the effectivity of bioagents adversely (Singh, 2003; Khan, 2003). In many cases bioagents fail to manage the disease effectively due to various reasons and they would be used successfully if could integrated with compatible chemical pesticides. Hence testing compatibility with commonly used fungicides and antibiotics in crop cultivation is very important. Application of other agricultural pesticides viz. insecticides and herbicides may also affect the effectivity of bioagents adversely but these are necessary to manage pest and weeds causing huge loss to the rice crop. Hence, these are commonly applied in rice cultivation now days. Testing the compatibility of bioagents with these pesticides is also very important for successful biological control of disease under conventional rice cultivation (Sirvi et al., 2013).

Bacterial leaf blight of rice caused by Xanthomonas oryzae pv. oryzae is the disease known to occur in epidemic proportions in many parts of the world. The severity and significance of damage caused by disease has necessitated the development of strategies to manage the diseases, so as to reduce crop loss and to divert epiphytotic (Rao and Kaufmann, 1977). Microbial antagonists occur in nature are host specific, virulent, self perpetuating and genetically stable. These also stimulate plant growth, even if there is no disease, which results in better yield (Kloepper and Schroth, 1978; Mishra and Sinha, 2000). Therefore, they are potential candidates for management of plant diseases. Biological control of bacterial blight disease of rice has very important role in organic crop production and integrated disease management. Attempts were made to manage bacterial leaf blight disease of rice by means of fungal antagonist, Trichoderma harzianum (Gangwar and Sinha, 2010; Gangwar, 2012; Gangwar and Sinha, 2012a,b\&c and Gangwar, 2013). Therefore, the present study was carried out to find out the compatibility of fungal bioagent ( $T$. harzianum) with different chemical pesticides.

\section{MATERIALS AND METHODS}

Present study was carried out in Rice Pathology Laboratory, Department of Plant Pathology, G. B. Pant University of Agriculture and Technology, Pantnagar. Trichoderma harzianum was isolated from rice phyloplane. T. harzianum was effective against bacterial leaf blight of rice pathogen, Xanthomonas oryzae pv. oryzae (Gangwar and Sinha, 2010 and Gangwar and Sinha, 2012a) and against bacterial leaf blight disease of rice under glasshouse (Gangwar and Sinha, 2012b) and field conditions (Gangwar, 2012 and Gangwar, 2013). Present study was carried to tested compatibility of T. harzianum 
with different chemical pesticides. Six fungicides (tricyclazole, chlorothalonil, carbendazim, copper oxychloride, propiconazole and mancozeb), one antibiotic (streptocycline), six insecticides (buprofezin, dichlorovas, triazophos, profenophos, quinalphos and monocrotophos) and five herbicides (anilophos, pretilachlor, butachlor, pendimethalin and 2,4-D) were evaluated for their compatibility with $T$. harzianum.

Potato dextrose agar (PDA) medium poisoned with different pesticides (fungicides, antibiotic, insecticides and herbicides) at 2000, 1000, 500 and 250 ppm concentration was poured in sterilized petri dishes. After solidification of PDA, $5 \mathrm{~mm}$ disc was cut from growing mycelium of $\mathrm{T}$. harzianum colony and was placed in the center of petri dishes. Petri dishes with unamended medium served as check. Three replications were maintained for each treatment. These petri dishes were incubated at $28 \pm 1{ }^{\circ} \mathrm{C}$ in BOD incubator. Periodic observations on radial growth and sporulation were recorded.

\section{RESULTS AND DISCUSSION}

All the chemical pesticides (fungicides, antibiotic, insecticides and herbicides) exhibited adverse effect on mycelial growth of T. harzianum but none of these was antisporulant.

Effect of fungicidesand antibiotic: Data presented in Table 1 revealed that maximum mean radial growth $(66.5 \mathrm{~mm})$ of $\mathrm{T}$. harzianum was recorded with streptocycline followed by copper oxychloride $(30.7 \mathrm{~mm})$ and mancozeb $(11.9 \mathrm{~mm})$. At lowest concentration (250 ppm), maximum radial growth was observed by streptocycline $(85.0 \mathrm{~mm})$ followed by copper oxychloride $(37.3 \mathrm{~mm})$ and mancozeb $(26.3 \mathrm{~mm})$. At 2000 ppm concentration, maximum radial growth of $\mathrm{T}$. harzianum was observed with copper oxychloride $(20.6 \mathrm{~mm})$ and streptocycline $(11.3 \mathrm{~mm})$. Copper oxychloride and streptocycline was compatible with T. harzianum at higher (2000 and $1000 \mathrm{ppm}$ ) and lower concentrations (500 and 250 ppm). Mancozeb was compatible only on lower concentrations (500 and $250 \mathrm{ppm}$ ). Viji et al . (1997) observed that the benzimidazole group of fungicides (carbendazim and benomyl) was toxic to the antagonists (Gliocladium virens, Trichoderma longibrachiatum and T. harzianum), while the organophosphorus fungicides (edifenphos and iprobenfos) were less toxic the antagonists. Mishra (1998) demonstrated insensitiveness of G. virens to Vitavax, Captan and Thiram. Singh and Singh (2003) reported that carboxin at 5,10 and $25 \mathrm{ppm}$ had no effect on the radial growth of T. virens isolates. Malathi and Doraisamy (2003) reported that Captan and Thiram were compatible with the fungal antagonist T. harzianum TH-5. The differential response of biocontrol agents to various fungicides might be due to their inherent resistance to most of fungicides and their ability to degrade chemicals (Papavizas, 1985 and Viji et al., 1997). Fungicides those are active against a narrow spectrum of plant pathogen but not against biocontrol agent offer an opportunity for integration of chemical and biocontrol agents. When biocides are applied in sub lethal doses, some fungal biocontrol agents (Trichoderma sp. etc.) are known to proliferate and produce antibiotics in soil (Papavizas, 1985). Further, their application may metabolically weaken the pathogen and make it vulnerable to potent biocontrol agents. The antagonists could tolerate $400 \mu \mathrm{M}$ of the organophosphorus fungicides compared with $4 \mu \mathrm{M}$ of the benzimidazole fungicides.

E ffect of insecticides: Table 2 depicts that all insecticides were compatible with $\mathrm{T}$. harzianum at all concentrations (2000, 1000, 500 and $250 \mathrm{ppm})$. Maximummean radial growth of T. harzianum (74.7 $\mathrm{mm}$ ) was measured with buprofezin which was followed by monocrotophos $(65.8 \mathrm{~mm})$ and dichlorovas $(60.0 \mathrm{~mm})$. Quinalphos showed minimum mean radial growth $(22.0 \mathrm{~mm})$ of T. harzianum. At lowest concentration (250 ppm), maximum radial growth $(85.0$ $\mathrm{mm})$ was shown by monocrotophos, which followed by buprofezin $(83.3 \mathrm{~mm})$ and dichlorovas $(71.6 \mathrm{~mm})$. At highest concentration $(2000 \mathrm{ppm})$, maximum radial growth $(66.3 \mathrm{~mm})$ was obtained by buprofezin which was followed by dichlorovas $(44.3 \mathrm{~mm})$ and monocrotophos (34.0 mm). Tiwari et al. (2004) recorded that Chlorpyrifos (dust), Methyl Parathion [parathionmethyl] (dust), Lindane (dust) and acephate (soluble powder) were not inhibitory to the mycelial growth of $T$. harzianum. Gowdar et al. (2004) reported that the maximum inhibition of T. harzianum $(74.37 \%$ ) was recorded at $1.25 \%$ Imidacloprid at 7 days after the treatment (DAT), and the minimum $(12.50 \%)$ at $0.25 \%$ Imidacloprid at 21 DAT.

Effect of her bicides: It is evident from table 3 that all the herbicides were compatible with $\mathrm{T}$. harzianum at all concentrations (2000, 1000, 500 and 250 ppm). Maximum mean radial growth $(45.7 \mathrm{~mm})$ of $\mathrm{T}$. harzianum was observed with anilophos, followed by butachlor $(42.5 \mathrm{~mm})$ and pendimethalin $(36.0 \mathrm{~mm})$. Maximum radial growth $(67.6 \mathrm{~mm})$ was observed at lowest concentration $(250 \mathrm{ppm})$ of anilophos, which was followed by 2,4-D $(63.0 \mathrm{~mm})$ and butachlor (61.6 mm). At higher concentrations (2000 and $1000 \mathrm{ppm})$, maximum radial growth (32.6 and $35.6 \mathrm{~mm}$, respectively) was observed with butachlor, followed by anilophos (26.6 and $34.6 \mathrm{~mm}$, respectively). Similarly, Desai and Kulkarni (2004) reported that captan, acephate, atrazine and 2,4-D were comparatively safe to the biological control agent. Ciraj (1996) concluded sulfonylurea based herbicides had no significant negative effect on antagonistic fungi Trichoderma species, and in some cases they stimulated growth of fungi. Rao and Divakar (2002) reported treatment with 50 ppm butachlor resulted in the increase of CFU of T. viride $24 \mathrm{~h}$ after treatment. 
Table 1. Compatibility of different fungicides and antibiotic with T. harzianum after 7 days of inoculation.

\begin{tabular}{lccccc}
\hline \multirow{2}{*}{ Treatment } & \multicolumn{5}{c}{ Radial gr owth T. harzianum $(\mathrm{mm})$} \\
\cline { 2 - 6 } & $2000 \mathrm{ppm}$ & $1000 \mathrm{ppm}$ & $500 \mathrm{ppm}$ & $250 \mathrm{ppm}$ & M ean \\
\hline Tricyclazole & 2.6 & 4.0 & 9.3 & 12.6 & 7.1 \\
Chlorothalonil & 4.0 & 4.3 & 5.3 & 8.0 & 5.4 \\
Carben dazim & 0.0 & 0.0 & 0.0 & 0.0 & 0.0 \\
Copper oxychloride & 20.6 & 32.3 & 32.6 & 37.3 & 30.7 \\
Streptocycline & 11.3 & 85.0 & 85.0 & 85.0 & 66.5 \\
Propicon azole & 0.0 & 0.0 & 0.0 & 0.0 & 0.0 \\
Manacozeb & 0.0 & 0.0 & 21.3 & 26.3 & 11.9 \\
Check & 85.0 & 85.0 & 85.0 & 85.0 & 85.5 \\
Mean & 15.4 & 26.3 & 29.8 & 31.7 & 25.8 \\
\hline CD at 5\% & A (concentrations) & $=0.51$ & & \\
& B (treatments) & $=0.71$ & \\
\end{tabular}

*Mean of three replications

Table 2. Compatibility of different insecticides with T. harzianum after 7 days of inoculation.

\begin{tabular}{lccccc}
\hline \multirow{2}{*}{ Treatment } & \multicolumn{5}{c}{ R adial gr owth T. ha rzianum (mm) } \\
\cline { 2 - 6 } & $2000 \mathrm{ppm}$ & $1000 \mathrm{ppm}$ & $500 \mathrm{ppm}$ & $250 \mathrm{ppm}$ & M ean \\
\hline Buprofezin & 66.3 & 73.3 & 76.0 & 83.3 & 74.7 \\
Dichlorovas & 44.3 & 56.3 & 68.0 & 71.6 & 60.0 \\
Triazophos & 17.3 & 34.3 & 41.0 & 45.0 & 34.4 \\
Profenophos & 18.6 & 31.0 & 45.3 & 56.0 & 37.7 \\
Quinalphos & 13.0 & 14.3 & 22.6 & 38.3 & 22.0 \\
Monocrotophos & 34.0 & 69.3 & 75.0 & 85.0 & 65.8 \\
Check & 85.0 & 85.0 & 85.0 & 85.0 & 85.0 \\
Mean & 39.8 & 51.9 & 59.0 & 66.3 & 54.2 \\
\hline CD at 5\% & A (concentrations) & $=1.00$ & \\
& B (treatments) & $=1.33$ & \\
& A x B & $=2.67$ & \\
\end{tabular}

*Mean of three replications

Table 3. Compatibility of different herbicides with T. harzianum after 7 days of inoculation.

\begin{tabular}{|c|c|c|c|c|c|}
\hline \multirow{2}{*}{ Treatment } & \multicolumn{5}{|c|}{ R adial growth T. har zianum (mm) } \\
\hline & $2000 \mathrm{ppm}$ & $1000 \mathrm{ppm}$ & $500 \mathrm{ppm}$ & $250 \mathrm{ppm}$ & M ean \\
\hline Anilophos & 26.6 & 34.6 & 54.0 & 67.6 & 45.7 \\
\hline Pretilachlor & 23.0 & 29.6 & 35.6 & 54.6 & 35.7 \\
\hline Butachlor & 32.6 & 35.6 & 40.0 & 61.6 & 42.5 \\
\hline Pendimethalin & 15.3 & 30.3 & 44.0 & 54.6 & 36.0 \\
\hline $2,4-\mathrm{D}$ & 9.3 & 10.3 & 31.3 & 63.0 & 28.5 \\
\hline Check & 85.0 & 85.0 & 85.0 & 85.0 & 85.0 \\
\hline Mean & 32.0 & 37.6 & 48.3 & 64.4 & 45.5 \\
\hline $\mathrm{CD}$ at $5 \%$ & $\begin{array}{l}\mathrm{A}(\text { concentrations }) \\
\mathrm{B} \text { (treatments) } \\
\mathrm{A} \times \mathrm{B}\end{array}$ & $\begin{array}{l}=0.83 \\
=1.01 \\
=2.03\end{array}$ & & & \\
\hline
\end{tabular}

*Mean of three replications

\section{Conclusion}

The present study revealed that different chemical pesticides viz. Copper oxychloride (fungicide) and streptocycline (antibiotic) buprofezin, monocrotophos, dichlorovas (insecticides) and anilophos, butachlor, pendimethalin, pretilachlor (herbicides) exhibited 
compatibility with fungal bioagent (T. harzianum) of bacterial leaf blight of rice. There are possibilities of deployment of compatible bioagents in rice cultivation. In the integrated disease management package, compatible pesticides can be incorporated along with bioagents for effective and sustainable disease management with lesser disturbance to agro-ecosystem.

\section{REFERENCES}

Ciraj, M. (1996). Impact of some sulfonylurea herbicides upon selected soil fungi. Sodobno kmetijstvo, 29(3): 99-108.

Desai, S.A. and Kulkarni, S. (2004). Effect of fungicides, insecticides and weedicides on the growth and sporulation of native Trichoderma harzianum Rifai. Karnataka J ournal of Agricultural Sciences, 17: 57-62.

Gangwar, G.P. (2012). Efficacy of commercial formulations of bioagent against bacterial leaf blight of rice. Ann. PI. Protec. Sci., 20(2): 389-391.

Gangwar, G.P. (2013). Efficacy of bioagents application rate against bacterial leaf blight of rice. Ann. PI. Protec. Sci., 21(1): 206-208.

Gangwar, G.P. and Sinha, A.P. (2010). Comparative antagonistic potential of Trichoder ma spp. against $X$ anthomonas oryzae pv. oryzae. Ann. PI. Protec. Sci., 18(2): 458-463.

Gangwar, G.P. and Sinha, A.P. (2012a). Comparative antagonistic potential of fungal and bacterial bioagents against Xanthomonas oryzae pv. oryzae. Ann. PI. Protec. Sci., 20(1): 154-159.

Gangwar, G.P. and Sinha, A.P. (2012b). Evaluation of Trichoderma spp. and fluorescent pseudomonads for the management of bacterial leaf blight of rice. Indian Phytopath., 65 (1): 89-91.

Gangwar, G.P. and Sinha, A.P. (2012c). Effect of time of application on fungal and bacterial bioagents against bacterial leaf blight of rice. Agric. Sci. Digest., 32 (2): 123-127.

Gowdar, S.B., Nargund, V.B., Patil, B.V. and Reddy, N.A. (2004). Preliminary studies on compatibility of imidacloprid with Trichoderma harzianum. Insect E nvironment. 10: 43-45.

Khan, A.A. (2003). Factors affecting efficacy of Trichoder ma spp. as biocontrol agents against sheath blight of rice. Ph.D. Thesis submitted to G.B. Pant University of Agriculture and Technology, Pantnagar.

Kloepper, J.W. and Schroth, M.N. (1978). Plant growth promoting rhizobacteria on radishes. In: Proceedings of the fourth International conference on Plant Pathogenic Bacteria. Vol. 2, Station de Pathogen Vegetable et. Phytobacteriology, INRA. Angers (eds.) Gibertclarey, Tours, pp. 879-882.

Malathi, P. and Doraisamy, S. (2003). Compatibility of Trichoderma harzianum with fungicides against Macrophomina phaseolina. Plant Disease Research Ludhiana, 18: 139-143.

Mishra, D.S. (1998). Comparative efficacy of some biocontrol agents against Rhizoctonia solani kuhn, the cause of sheath blight of rice M. Sc. (Ag) Thesis, G.B. Pant University of Agric. \& Tech. Pantnagar, India, pp 242.

Mishra, D.S. and Sinha, A.P. (2000). Plant growth-promoting activity of some fungal and bacterial agents on rice seed germination and seedling growth. Trop. Agric. 77: 188-191.

Papavizas, GC. (1985). Trichoderma and G liocladium: Biology and potential for biological control. Ann. Rev. Phytopath., 23: $23-54$.

Rao, C.V.R. and Divakar, B.J. (2002). Effect of three pesticides on the fungal bioagent, Trichoderma viride. Frontiers in Microbial. Biotechnol. and PI. Path., 24: 183186.

Rao, P.S. and Kauffman, H.E. (1977). Potential yield losses in dwarf rice varieties due to bacterial blight of India. Phytopath Zeits., 90(3): 281-284.

Singh, G. and Singh, U.S. (2003). Effect of pH, temperature and carboxin on the growth of mutants of Trichoderma virens. Ann. PI. Protec. Sci., 11: 167-168.

Singh, R. (2003). Factors affecting biocontrol potential of Pseudomonas fluorescens against sheath blight of rice. Ph.D. Thesis submitted to G.B. Pant University of Agriculture and Technology, Pantnagar, pp. 262.

Sirvi, S.L., Jat, A.L., Choudhary, H.R., Jat, N., Tiwari, V. K. and Singh, N. (2013) Compatibility of bio-agents with chemical pesticides: an innovative approach in insect-pest management. Pop. K heti, 1(1): 62-67.

Tiwari, R.K.S., Rajput, ML., Singh, A. and Thakur, B.S. (2004). Non-target effect of insecticides on the mycelial growth of Trichoderma harzianum (Rifai) Indian J ournal of Plant Protection, 32: 140-141.

Viji, G., Manibhushanrao, K. and Baby, U.I. (1997). Nontarget effect of systemic fungicides on antagonistic microflora of Rhizoctonia solani. Indian Phytopath., 50: 324-328. 